\title{
A New Genus and Species of Diplodactylid Gecko (Reptilia: Squamata: Diplodactylidae) from Northwestern New Caledonia ${ }^{1}$
}

\author{
Aaron M. Bauer, ${ }^{2,3}$ Todd Jackman, ${ }^{2}$ Ross A. Sadlier, ${ }^{4}$ and Anthony H. Whitaker ${ }^{5}$
}

\begin{abstract}
A new genus and species of diplodactylid gecko, Oedodera marmorata Bauer, Jackman, Sadlier \& Whitaker, is described from low-elevation maquis habitat near Paagoumène in the northwest of the Province Nord, New Caledonia. The new gecko is a robust form that is superficially similar to members of the genus Bavayia Roux but differs in several digital characteristics, the presence of a patch (versus 1-2 rows) of precloacal pores, and a uniquely swollen neck. In addition, molecular data indicate that the new form is the basal member of the entire radiation of New Caledonian diplodactylids. The new species is at risk due to wildfires, introduced predators and perhaps competitors, and planned mine development into part of its range.
\end{abstract}

The endemic geckos of New Caledonia are represented by three recognized genera: Bavayia Roux, Eurydactylodes Wermuth, and Rhacodactylus Fitzinger (Bauer and Sadlier 2000), all of which are included in the recently redefined and restricted family Diplodactylidae (Han et al. 2004). The last two of these are quite morphologically distinctive and Eurydactylodes, in particular, is characterized by a large number of autapomorphic traits (Bauer 1990, Böhme and Sering 1997). Bavayia, however, comprises relatively nondescript species with mostly plesiomorphic features. Although Rbacodactylus has been the subject of several phylogenetic analyses (Bauer 1990, Good et al. 1997, Vences et al.

${ }^{1}$ This research was supported by grant DEB 0108108 from the National Science Foundation to A.M.B. and T.J. Manuscript accepted 24 January 2005.

2 Department of Biology, Villanova University, 800 Lancaster Avenue, Villanova, Pennsylvania 19085-1699 (phone: 1-610-519-4857; fax: 1-610-519-7863; e-mail: aaron.bauer@villanova.edu; todd.jackman@villanova. edu).

${ }^{3}$ Corresponding author.

${ }^{4}$ Department of Herpetology, Australian Museum, 6 College Street, Sydney 2000, New South Wales, Australia (e-mail: rosss@austmus.gov.au).

${ }^{5}$ Whitaker Consultants, 270 Thorpe-Orinoco Road, Orinoco, R.D. 1, Motueka 7161, New Zealand (e-mail: whitaker@ts.co.nz).

Pacific Science (2006), vol. 60, no. 1:125-135

(C) 2006 by University of Hawai'i Press

All rights reserved
2001), Bavayia has only been studied phylogenetically in the context of an unpublished allozyme study (Wright 1999). Although the more widespread species of Bavayia have been regarded as probable species complexes (Bauer 1990, Bauer and Sadlier 1993, Wright et al. 2000), no comprehensive review of the group has yet been undertaken.

Beginning in 2001, we undertook two major projects that now allow a thorough revision of Bavayia: a herpetofaunal survey of previously unstudied habitats in northwestern New Caledonia (Whitaker et al. 2004) and a molecular phylogenetic analysis of the endemic lizard fauna of New Caledonia as a whole. In the course of our research, the discovery of novel new taxa has challenged the existing views regarding generic composition of the New Caledonian diplodactylid fauna. For example, the discovery of seven new species allied to Bavayia validiclavis Sadlier and the analysis of mitochondrial and nuclear sequence data from this clade has necessitated the recognition of a fourth New Caledonian endemic genus to maintain the monophyly of Bavayia (A.M.B., T.J., and R.A.S., unpubl. data). We here report on a robust new gecko inhabiting lowland maquis vegetation in the area near Paagoumène in the northwest of the Province Nord, New Caledonia, that likewise does not fit comfortably into any existing genus. This distinctive new species is described herein and allocated to a new, monotypic genus. 


\section{MATERIALS AND METHODS}

\section{Morphology}

Specimens from the collections of the Australian Museum (AMs), California Academy of Sciences (CAs), and Muséum National d'Histoire Naturelle, Paris (MNHN), were examined under a dissecting microscope. The following measurements were taken with digital calipers (to the nearest $0.1 \mathrm{~mm}$ ): snout-vent length (SVL; from tip of snout to vent), trunk length (TrunkL; distance from axilla to groin measured from posterior edge of forelimb insertion to anterior edge of hindlimb insertion), crus length (CrusL; from base of heel to knee), tail length (TailL; from vent to tip of tail), tail width (TailW; measured at widest point of tail), head length (HeadL; distance between retroarticular process of jaw and snout tip), head width (HeadW; maximum width of head), head height (HeadH; maximum height of head, from occiput to underside of jaws), ear length (EarL; longest dimension of ear), forearm length (ForeaL; from base of palm to elbow), orbital diameter (OrbD; greatest diameter of orbit), nares to eye distance (NarEye; distance between anteriormost point of eye and nostril), snout to eye distance (SnEye; distance between anteriormost point of eye and tip of snout), eye to ear distance (EyeEar; distance from anterior edge of ear opening to posterior corner of eye), internarial distance (Internar; distance between nares), and interorbital distance (Interorb; shortest distance between left and right supraciliary scale rows). Unless otherwise stated, counts and measurements were made on right side of specimens.

Preserved specimen photographs were taken with a digital camera. Radiographic observations were made using a closed-cabinet $\mathrm{X}$-ray system.

\section{Molecular Methods}

Genomic DNA was extracted using the Qiagen QIAmp tissue kit. PCR amplification was conducted under a variety of thermocyler parameters using a variety of primers (A.M.B., T.J., and R.A.S., unpubl. data). Products were visualized via $1.5 \%$ agarose gel electrophoresis.
Cycle-sequencing reactions were performed using a primer cycle sequencing ready reaction kit (Applied Biosystems BigDye). The resulting products were purified using a magnetic bead purification kit (SeqClean). Purified sequencing reactions were analyzed on an automated sequencer (ABI 3700). Negative controls were included in every reaction, complementary strands were sequenced, and sequences were manually checked using the original chromatograph data. All sequences will be deposited in the GenBank database, and those derived from the new species described herein are accessioned there as AY 858954-60.

\section{Pbylogenetic Analyses}

Phylogenetic trees were estimated using parsimony, likelihood, and Bayesian analysis. PAUP* 4.0b10a (Swofford 2002) was used to estimate parsimony and likelihood trees. Parsimony searches were conducted with 100 heuristic searches using random addition of sequences. Nonparametric bootstrap resampling was used to assess support for individual nodes using 1,000 bootstrap replicates with 10 random-addition searches. For maximum likelihood analyses, ModelTest version 3.5 (Posada and Crandall 1998) was used to compare different models of sequence evolution with respect to the data. The chosen model was used to estimate parameters on the most parsimonious tree. These likelihood parameters were fixed and the overall most parsimonious trees were used as starting trees for branch swapping in 25 heuristic searches with random addition of taxa to find the overall best likelihood topology. To estimate a phylogenetic tree with a Bayesian framework MrBayes 3.0 (Huelsenbeck and Ronquist 2001) was used with the model chosen using ModelTest 3.5.

\section{SYSTEMATICS}

Genus Oedodera Bauer, Jackman, Sadlier \& Whitaker, n. gen.

Type species: Oedodera marmorata Bauer, Jackman, Sadlier \& Whitaker, n. sp. 


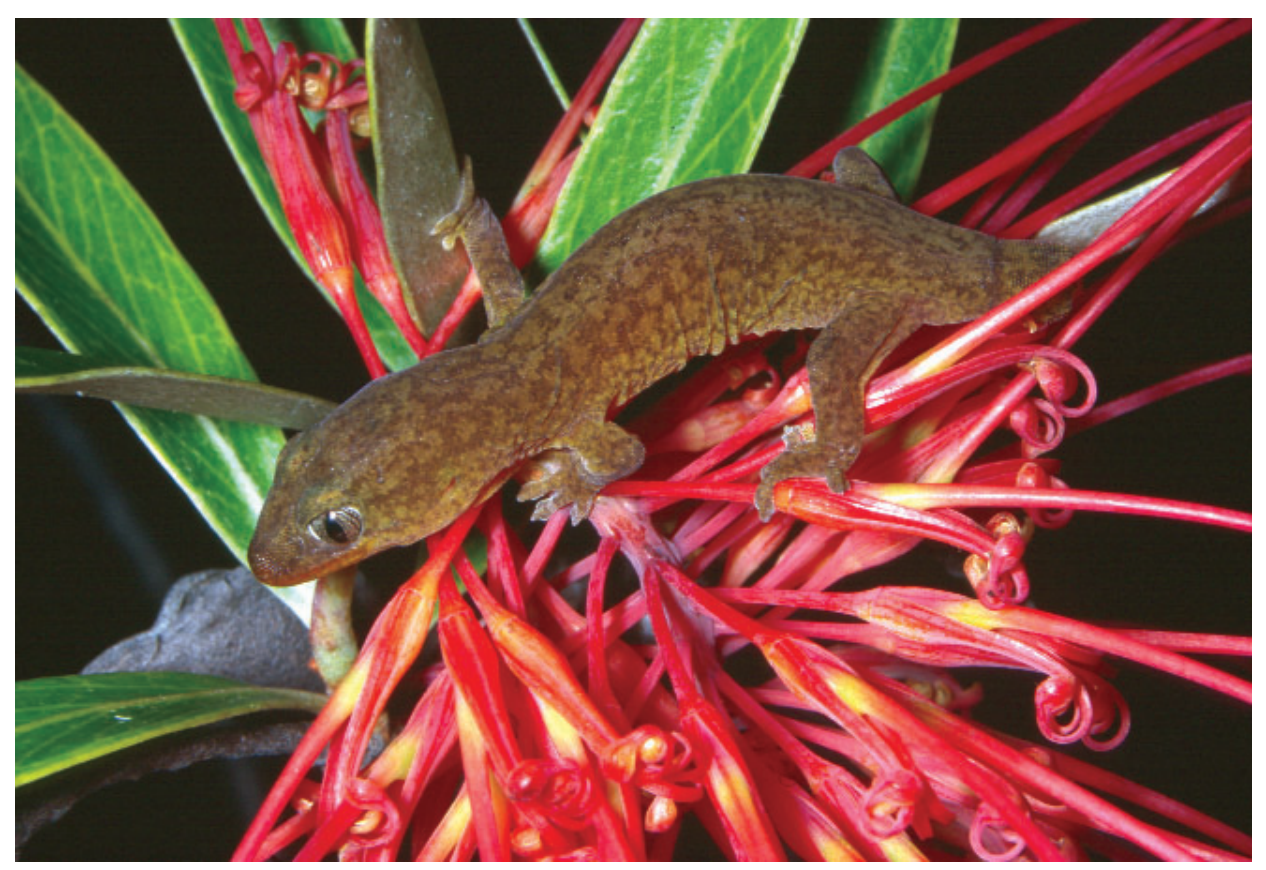

PLATE I. Juvenile Oedodera marmorata (AMS R 161254) in life, illustrating marbled dorsum and yellowish undertones, especially on lower margins of the body. Specimen is shown on a flower of Grevillea meisneri Montrouzier (Proteaceae), an endemic lowland maquis plant that occurs at the localities where O. marmorata has been collected.

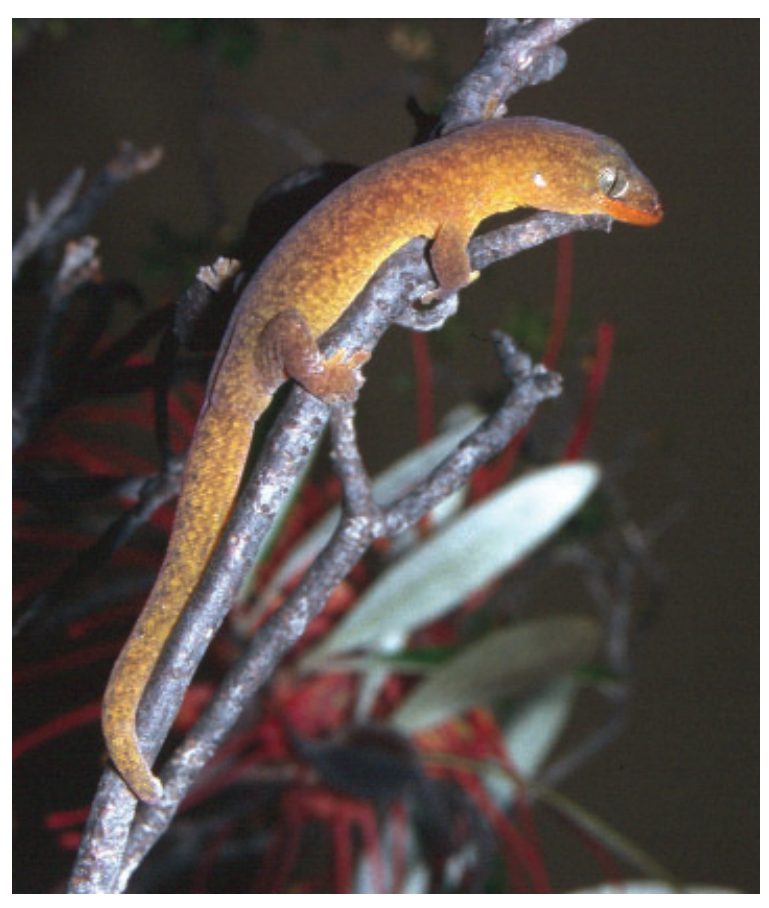

Plate II. Juvenile Oedodera marmorata (AMS $\mathrm{R}$ 161256) in life. Note yellowish markings on flanks and tail and orange labial scales. Twig on which specimen is climbing is typical of narrow perches on which most specimens were found. 
Diagnosis: Oedodera can be distinguished from all other diplodactylid genera (sensu Han et al. 2004) by the following combination of derived character states: all subdigital lamellae (excluding apical scansors) undivided; reduced claw of digit I of manus and pes situated between an asymmetrical pair of apical scansors; medial apical scansor present on digit II of one or more feet (condition variable); neck distinctly swollen, nearly as wide as the widest part of head; precloacal pores in multiple rows or a patch.

ETYMology: The generic name is derived from the Latinized version of the Greek roots oidema (a swelling) and dere (neck) and refers to the characteristic swollen appearance of the neck in all specimens of this genus. The name is feminine.

ReCOGNIZed species: Oedodera marmorata Bauer, Jackman, Sadlier \& Whitaker, n. sp.

Oedodera marmorata Bauer, Jackman, Sadlier \& Whitaker, n. sp.

Figures 1-2, Plates I-II

TYPE MATERIAL: Holotype: MNHN 2004.0015, Creek à Paul, Sommet Noir, Paagoumène, $11 \mathrm{~km} \mathrm{NW}$ Koumac, Province Nord, New Caledonia, 20 29' 21.1" S, $164^{\circ}$ $11^{\prime} 49.5^{\prime \prime} \mathrm{E}, 20 \mathrm{~m}$, collected by A. H. Whitaker and V. A. Whitaker, 19 October 2001. Paratypes: AMS R 161257, 161259, CAS 230934, same data as holotype; AMs R 161263, Ruisseau des Gaïacs, Paagoumène, 6 $\mathrm{km}$ NW Koumac, Province Nord, New Caledonia, $20^{\circ} 31^{\prime} 16.2^{\prime \prime} \mathrm{S}, 164^{\circ} 14^{\prime} 40.6^{\prime \prime} \mathrm{E}$, $30 \mathrm{~m}$, collected by A. H. Whitaker and V. A.
Whitaker, 21 October 2001; cas 230935-36, Ruisseau des Gaïacs, Province Nord, New Caledonia, $20^{\circ} 30^{\prime} 58^{\prime \prime} \mathrm{S}, 164^{\circ} 14^{\prime} 55^{\prime \prime} \mathrm{E}$, $30 \mathrm{~m}$, collected by T. Jackman, R. A. Sadlier, A. M. Bauer, S. A. Smith, and G. WatkinsColwell, 24 January 2003; cas 230937, Sommet Noir, Paagoumène, 11 km NW Koumac, Province Nord, New Caledonia, 20 $30^{\prime}$ $06.0^{\prime \prime} \mathrm{S}, 164^{\circ} 12^{\prime} 01.6^{\prime \prime} \mathrm{E}, 30 \mathrm{~m}$, collected by A. H. Whitaker and V. A. Whitaker, 21 October 2001.

ADDITIONAL MATERIAL EXAMINED: AMS R 161249, 161254, 161256, cAs 230938, same data as holotype; cas 230939, same data as CAS 230937.

ETYMOlogy: The specific epithet marmorata is Latin for "marbled" and refers to the dorsal patterning of the species. It is feminine, matching the generic name in gender.

DiAgnosis: Oedodera marmorata is a moderately sized (to $61 \mathrm{~mm} \mathrm{SVL}$ ), robust-bodied diplodactylid. It may be distinguished from all other New Caledonian diplodactylid geckos by its swollen neck (Figure 1), presence of precloacal pits in females, and apical scansors on digit II (variable; Figure 2). It may further be differentiated from Eurydactylodes by its depressed (versus compressed) body and the absence of enlarged head scales and a caudal chemical defensive system. It differs from all Rhacodactylus by its smaller size (maximum 61 $\mathrm{mm}$ SVL versus $125+\mathrm{mm}$ SVL), absence of lateral and tail base skin folds, and absence of extensive digital webbing. It differs from Bavayia and a newly erected genus (A.M.B., T.J., and R.A.S., unpubl. data) in its undivided subdigital scansors (versus distal scansors divided), and marbled dorsal pattern

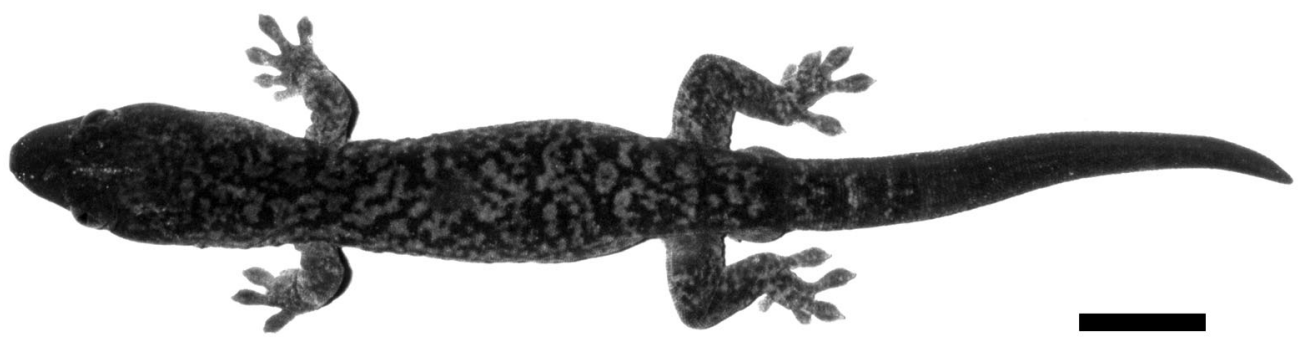

FiguRe 1. Holotype of Oedodera marmorata (MNHN 2004.0015). Note large head, wide neck, relatively slender tail, and marbled dorsal pattern. Scale bar $=10 \mathrm{~mm}$. 


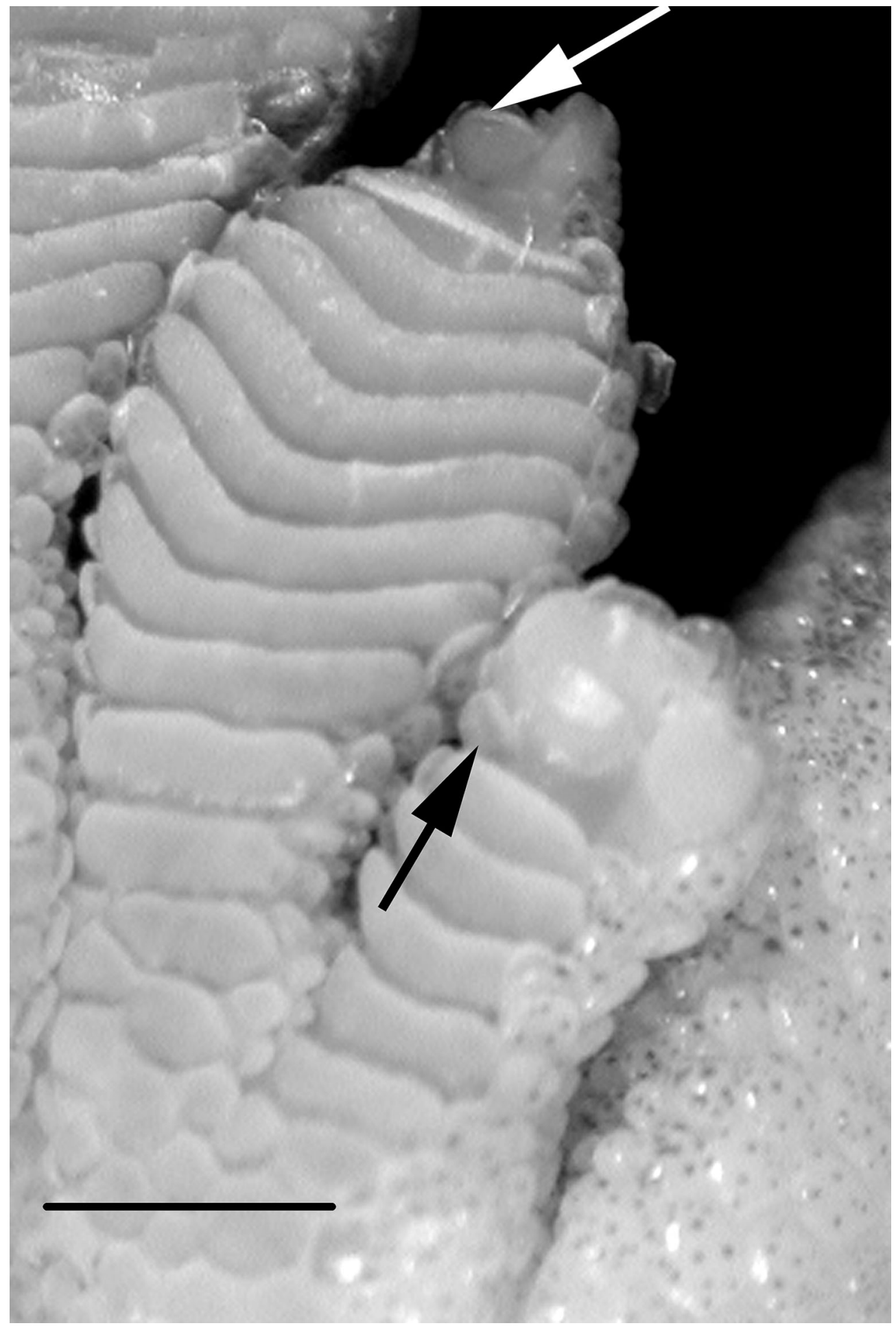

FIGURE 2. Ventral view of left pes of $O$. marmorata (holotype, MNHN 2004.0015) illustrating undivided subdigital scansors, medial apical scansor on digit II (white arrow), and small rounded scale on medial side only in gap between subdigital lamellae and apical scansors of digit I (black arrow). Scale bar $=1 \mathrm{~mm}$. 
(versus transverse chevrons or blotches, longitudinal stripes, or patternless). Precloacal pores of adult male $O$. marmorata are arranged in two rows or in a patch consisting of three rows of pores. Among currently recognized taxa, this distinguishes it from $B$. sauvagii (Boulenger); B. exsuccida Bauer, Whitaker \& Sadlier; B. pulchella Bauer, Whitaker \& Sadlier; B. septuiclavis Sadlier; B. geitaina Wright, Bauer \& Sadlier; and B. ornata Roux, all of which possess only a single row of pores. The presence of a medial apical scansor on digit II is unique among diplodactylids. Although this feature is variable among $O$. marmorata (absent in 54\% of all specimens examined; see Variation following Description), if present it is sufficient by itself to diagnose a particular specimen.

DESCRIPTION (data from adult male holotype, MNHN 2004.0015): SVL $61.0 \mathrm{~mm}$; TailL $45.1 \mathrm{~mm}$ (of which $30.7 \mathrm{~mm}$ are regenerated); TrunkL $24.8 \mathrm{~mm}$; HeadL $16.2 \mathrm{~mm}$; HeadW $11.1 \mathrm{~mm}$; HeadH $7.3 \mathrm{~mm}$; SnEye $6.3 \mathrm{~mm}$; OrbD $4.1 \mathrm{~mm}$; EyeEar $6.1 \mathrm{~mm}$. Body moderately long (TrunkL $=41 \%$ SVL), robust, slightly depressed. Head oblong, large (HeadL $=27 \%$ SVL), relatively wide (HeadW $=68 \%$ HeadL) and somewhat depressed (HeadD $=45 \% \mathrm{HL}$ ), not well demarcated from neck, which is approximately as wide as head (Figure 1); interorbital/ frontal region somewhat depressed, nasal region with a distinct, shallow indentation; canthus weakly inflated; snout relatively long (SnEye $=39 \%$ HeadL), much longer than eye diameter ( $\mathrm{OrbD}=66 \%$ SnEye). Scales on dorsum of snout approximately 2-3 times the diameter of those on occipital region, becoming larger on lateral surfaces of snout and in first 1-2 rows of scales posterior to supranasals. Eye large $(\mathrm{OrbD}=26 \% \mathrm{HeadL})$; pupil oval, margins crenellated. Ear opening approximately 3 times as high as wide, canted posterodorsally to anteroventrally at $45^{\circ}$; eye to ear distance longer than diameter of eyes $($ EyeEar $=148 \%$ OrbD $)$. Rostral rectangular, broader $(2.8 \mathrm{~mm})$ than high $(1.6 \mathrm{~mm})$, divided dorsally by a very short rostral crease, contacted posteriorly by one large pentagonal internasal and two large supranasals, each comparable in size and shape to internasal but with a narrow lateral extension contacting the nostril rim (on right side this extension is separated from the remainder of the supranasal by a suture), contacted posteroventrally by first supralabial. Nostrils oval, laterally oriented, surrounded by rostral, two postnasals, a crescentic nasal separating the nostril from two additional postnasals, and broadly by first supralabial. Mental triangular, broader (1.8 $\mathrm{mm})$ than deep $(1.4 \mathrm{~mm})$. First two left infralabials elongate, right side fragmented, with first infralabial divided into two major scales; first infralabials in broad contact with one another posterior to mental scale, each in contact posteriorly with an enlarged, median, pentagonal (narrowest apex anterior) postmental. Postmental bordered laterally by one enlarged (40-50\% size of postmental) chin scale on each side and posteriorly by typical granular chin scales. Scales in 2-3 rows medial to infralabials somewhat enlarged and elongate. Ten enlarged supralabial scales, posteriormost only about 3 times size of rictal scales, 8 (left) or 9 (right) supralabial scales to midpoint of orbit; 10 (left)-11 (right) enlarged infralabial scales; 31 scale rows between supraciliaries, 14 scale rows across frontal bones at midpoint of orbit.

Dorsal scales tiny, homogeneous, slightly conical, granular; ventral scales 2-3 times diameter of dorsals, smooth, flattened, juxtaposed to subimbricate, enlarged in precloacal region. Posterior abdominal scales rounded, midabdominal scales slightly elongate. Approximately 141 scale rows around midbody. No ventrolateral skin folds. Scales of limbs not differing from dorsals. Scales on palms and soles smooth, flattened. Fore- and hindlimbs very short and thick (ForeaL/SVL ratio 0.11; CrusL/SVL ratio 0.14 ), axillary pocket weakly developed. Digits short, all bearing claws, those on digit I of both manus and pes reduced and partially sheathed, remaining claws long and strongly recurved; relative length of digits of manus: $\mathrm{IV} \sim \mathrm{III}>$ $\mathrm{V}>\mathrm{II}>\mathrm{I}$, and of pes: $\mathrm{IV} \sim \mathrm{V}>\mathrm{III}>\mathrm{II}>$ I; digits moderately webbed, especially between digits III and IV of pes and III, IV, and V of manus; digits III and IV of pes tightly bound along length of elongate metatarsals. Subdigital lamellae all unpaired, distal 
lamellae beneath widest portion of pad somewhat bowed, with lateral margins gently angled distally (except for digit I). Claw of digit I, manus and pes, lies between a smaller lateral and a larger (twice size of lateral) medial apical scansor. Digit I of pes only with a small rounded scale on medial side only in gap between subdigital lamellae and apical scansors; digit II of manus and pes (absent on right pes) with a small, round, medial apical scansor adjacent to claw (Figure 2). Lamellar counts from right (and left) sides 6-10-12-12-11 (6-10-12-13-11) manus and 5-10-13-15-12 (6-10-13-15-11) pes (excludes apical scansors of digit I).

Large precloacal pores in a patch of somewhat enlarged scales, arranged in three rows (anterior to posterior) of 3, 7, and 5. No femoral pores or enlarged femoral scales. Hemipenial bulge large; cloacal spurs on raised base just posterior to hindlimb insertion, with two enlarged, smooth, laterally compressed scales. Tail (approximately 68\% regenerated in holotype) $74 \%$ of snout-vent length, thick, roughly round in cross section. Caudal scales small, flat, juxtaposed to weakly subimbricate, squarish with rounded free margins, arranged in regular rows. Surface of tail weakly segmented, caudal scale rows forming whorls, each whorl 8 dorsal scale rows and 6 ventral scale rows long; ventral caudals 1.5 times larger than dorsals, midventral caudal scales not enlarged. Scales of pygal region smaller than those of postpygal region. Rows of scales on regenerated portion of tail not uniform in size, typically somewhat smaller than scales of pygal region of tail.

Color in preservative (based on holotype): Dorsum marbled purplish brown on light brown, forming irregular reticulations over the entire dorsum from parietal to tail base. Snout light brown to midbrown with a darker brown supranasal and loreal area and rostral streak; area above and behind orbit also somewhat darker than surrounding surfaces. Labial scales mottled midbrown and cream. Iris opalescent with brown reticulations. Limbs similar to dorsum, with purplish brown reticulations and mottling. Dorsal surface of original portion of tail with large brown middorsal blotches on a buff back- ground. Regenerated portion buff with scattered diffuse darker areas. Venter, including palms, soles, and subdigital surfaces, buff to beige with scattered light brown scales, especially on trunk between axilla and groin. Tail venter buff with irregular transversely oriented areas of light pigmentation.

In life the ventral surfaces, especially the cloacal region, as well as the supralabial scales and flanks, have a yellowish tinge (Plate I). At night the animals appear especially yellow, with the lighter areas of the marbled dorsum ranging from pale yellowish brown to almost canary yellow. The labial scales and nostril rims may be yellowish to orange (Plate II). The bolder yellow portions of the pattern are distinctly faded by day, and the animals appear brown. Juveniles are more brightly colored than adults.

osteology: Vertebral counts are typical for diplodactylid geckos, with 26 presacral and 2 sacral vertebrae. The first three cervical vertebrae are without ribs, as is the last presacral (lumbar) vertebra. The caudal skeleton includes 5 pygal vertebrae and 3.5 postpygals anterior to the regenerated portion of the tail in the holotype. Paratype ams R 161258 has 11.5 postpygals in the original portion of the tail. The phalangeal formulas of the manus and pes are unreduced, 2-3-4-5-3 and 2-3-4$5-4$, respectively. Total tooth loci in upper jaw of holotype 61 , of which 9 are in premaxilla; total mandibular tooth loci 51. A single pair of crescentic cloacal bones is present in the holotype and all other males.

VARIATION: Comparative mensural data for the holotype and paratypes are given in Table 1. Meristic characters of paratypes are mostly similar to those of the holotype and are mentioned hereafter if they differ. The medial apical scansor on digit II is variably present among the paratypes. AMs R 161263 possesses the scansor on all feet, whereas cas 230937 has this feature on both manus, but only on the right pes; cAs 230935 has the apical scansor well developed on both manus and only weakly on the left pes. AMs R 161257 , AMS R 16159, CAS 230934, and cas 230936 lack the apical scansor on digit II altogether. Among nontype specimens the apical pad is present on the left manus only of cAs 230938 
TABLE 1

Mensural Data for Types of Oedodera marmorata, n. sp.

\begin{tabular}{lcccccccc}
\hline \hline & MNHN & CAS & AMS & CAS & AMs & CAS & CAS & AMS \\
& 2004.0015 & 230935 & R 161259 & 230937 & R 161263 & 230934 & 230936 & R 161257 \\
Parameter & Holotype & Paratype & Paratype & Paratype & Paratype & Paratype & Paratype & Paratype \\
\hline Sex & Male & Male & Male & Male & Female & Female & Female & Female \\
SVL & 61.0 & 59.8 & 58.2 & 48.7 & 59.9 & 57.7 & 56.9 & 51.8 \\
ForeaL & 6.8 & 6.5 & 6.4 & 6.5 & 6.4 & 6.0 & 6.5 & 6.1 \\
CrusL & 5.4 & 8.3 & 8.2 & 7.3 & 7.5 & 7.8 & 7.9 & 7.2 \\
TailL & 45.1 & 29.2 & 27.8 & 24.9 & 43.5 & 51.1 & 6.9 & 48.2 \\
(regen.) & 30.1 & 20.6 & Broken & Broken & 38.3 & 17.6 & Broken & 38.3 \\
TailW & 5.4 & 4.5 & 5.4 & 4.3 & 7.3 & 6.0 & N/A & 5.7 \\
TrunkL & 24.8 & 26.8 & 26.3 & 20.0 & 25.5 & 24.3 & 23.9 & 25.4 \\
HeadL & 16.2 & 14.2 & 14.6 & 11.9 & 14.8 & 14.4 & 14.2 & 13.1 \\
HeadW & 11.1 & 9.6 & 10.5 & 9.9 & 11.2 & 10.2 & 10.3 & 9.3 \\
HeadH & 7.3 & 6.5 & 7.5 & 7.2 & 7.5 & 6.7 & 6.5 & 7.1 \\
OrbD & 4.1 & 4.2 & 4.0 & 3.6 & 3.7 & 4.1 & 4.0 & 3.8 \\
EyeEar & 6.1 & 6.0 & 5.2 & 5.0 & 5.7 & 5.8 & 6.1 & 4.8 \\
SnEye & 6.3 & 6.2 & 5.9 & 5.4 & 5.9 & 5.7 & 5.6 & 5.2 \\
NarEye & 4.5 & 4.2 & 3.8 & 3.6 & 4.1 & 4.0 & 4.0 & 3.9 \\
Interorb & 5.2 & 4.6 & 5.5 & 4.4 & 4.6 & 4.8 & 4.7 & 4.2 \\
EarL & 2.0 & 1.4 & 1.4 & 2.0 & 1.2 & 1.4 & 1.4 & 1.7 \\
Internar & 2.4 & 2.3 & 2.3 & 2.1 & 2.1 & 2.2 & 1.9 & 1.8 \\
\hline
\end{tabular}

Note: Abbreviations as in Materials and Methods. All measurements in mm.

and on the right manus only of AMs R 161249 and is lacking from all feet in AMs R 161254, ams R 161256, and cas 230939. The asymmetrical scale proximal to the apical scansors of digit I occurs among the paratypes only in AMS R 161263. The fragmented anterior infralabials of the holotype are unique among the specimens examined, being represented by single, very elongate scales in all the paratypes. Precloacal pores are arranged in rows of 2, 9, and 5 (AMS R 161259), 8 and 8 (CAS 230937), and 5 and 4 (CAS 230935) among male paratypes. In female paratypes, the precloacal scales lack pores filled with secretions but bear empty, slitlike pits arranged in multiple rows: 8 and 5 (AMs R 161257); 1, 9, and 6 (CAS 230934); and 6, 5, and 2 (aMs R 161263); or in a single row of 5 (CAS 230936).

Color pattern is generally similar among all specimens examined, although in CAS 230936 the purplish brown areas are distributed as dense speckling rather than as marbling or reticulations. This specimen also has a darker (light brown versus buff) venter. The original portion of the tail in cas 230934 is marked by ill-defined alternating light brown and purplish brown transverse markings.

\section{Distribution and Habitat}

Oedodera marmorata is known only from three lowland sites $(<60 \mathrm{~m}$ asl $)$ on the western slopes of Dôme de Tiébaghi, east southeast of Paagoumène (Figure 3). The type locality at Creek à Paul lies just north of Sommet Noir $(178 \mathrm{~m})$. The most distant site, $5 \mathrm{~km}$ away, is at Ruisseau de Gaïacs, to the south of Ora (443 m). Dôme de Tiébaghi is one of a number of isolated ultramafic massifs lying along the northwest coast of New Caledonia (Sautter 1981), but the species has not been found on Tiébaghi proper, despite several searches (Whitaker et al. 2004). It seems inconceivable that $O$. marmorata should be restricted to this tiny area of lowland, given that the area is contiguous with other such lowland maquis around the massif and beyond; however, it has not yet been found elsewhere. A number of animal and plant species 


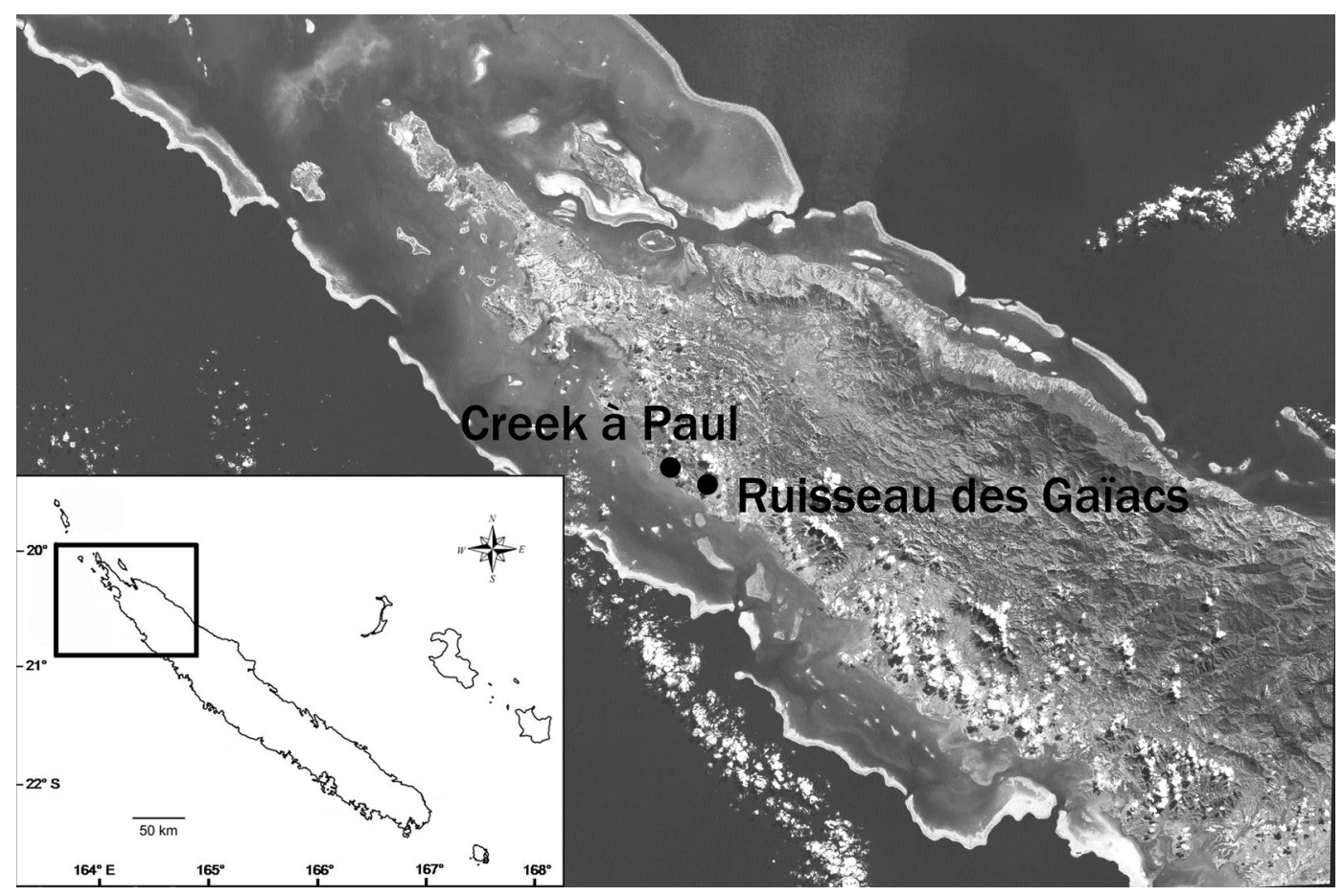

Figure 3. Landsat 7 image of northern portion of Province Nord, New Caledonia, showing localities where Oedodera has been collected. The Sommet Noir locality lies just south of Creek à Paul. Image from Millenium Coral Reef Landsat Archive.

are endemic to each of the northwestern ultramafic isolates, including Dôme de Tiébaghi (Jaffré et al. 1987; A.M.B., T.J., and R.A.S., unpubl. data), or to combinations of several such areas (Sadlier et al. 2004). We know of no other species, however, that are restricted to the Paagoumène (Sommet Noir, Ora) area exclusive of Tiébaghi itself, although Cossinia trifoliata (Baillon) Radlk. (Sapindaceae) has been recorded only from Paagoumène and Tinip, a nonultramafic area to the south of Koumac (Jaffré et al. 1987).

All specimens were found at night, active on maquis scrub vegetation (Figure 4), chiefly only 1-2 $\mathrm{m}$ above the ground. Two individuals were observed feeding on honeydew (Whitaker et al. 2004). Two eggs were present in several females (AMS R 161257, AMs R 161263, CAS 230936). In the largest female, AMs R 161263 , these measure 13.7 by 6.7 $\mathrm{mm}$ and 14.5 by $6.7 \mathrm{~mm}$ (based on radio- graphs). The habitat surrounding Sommet Noir and Ora is not very diverse and the only other reptiles found at the sites of collection were Hemidactylus garnotii Duméril \& Bibron, H. frenatus Duméril \& Bibron, Eurydactylodes agricolae Henkel \& Böhme, Rhacodactylus auriculatus (Bavay), Caledoniscincus baplorbinus (Günther), and C. aff. austrocaledonicus (Bavay).

\section{Phylogeny}

In both maximum parsimony and Bayesian analyses Oedodera is retrieved as the sister group to all remaining New Caledonian diplodactylid geckos. Although bootstrap values supporting the monophyly of the remaining taxa, exclusive of Oedodera, are low (64\%), there is no molecular support for its inclusion in Bavayia (which it most closely resembles), and the only alternative to the erection of 


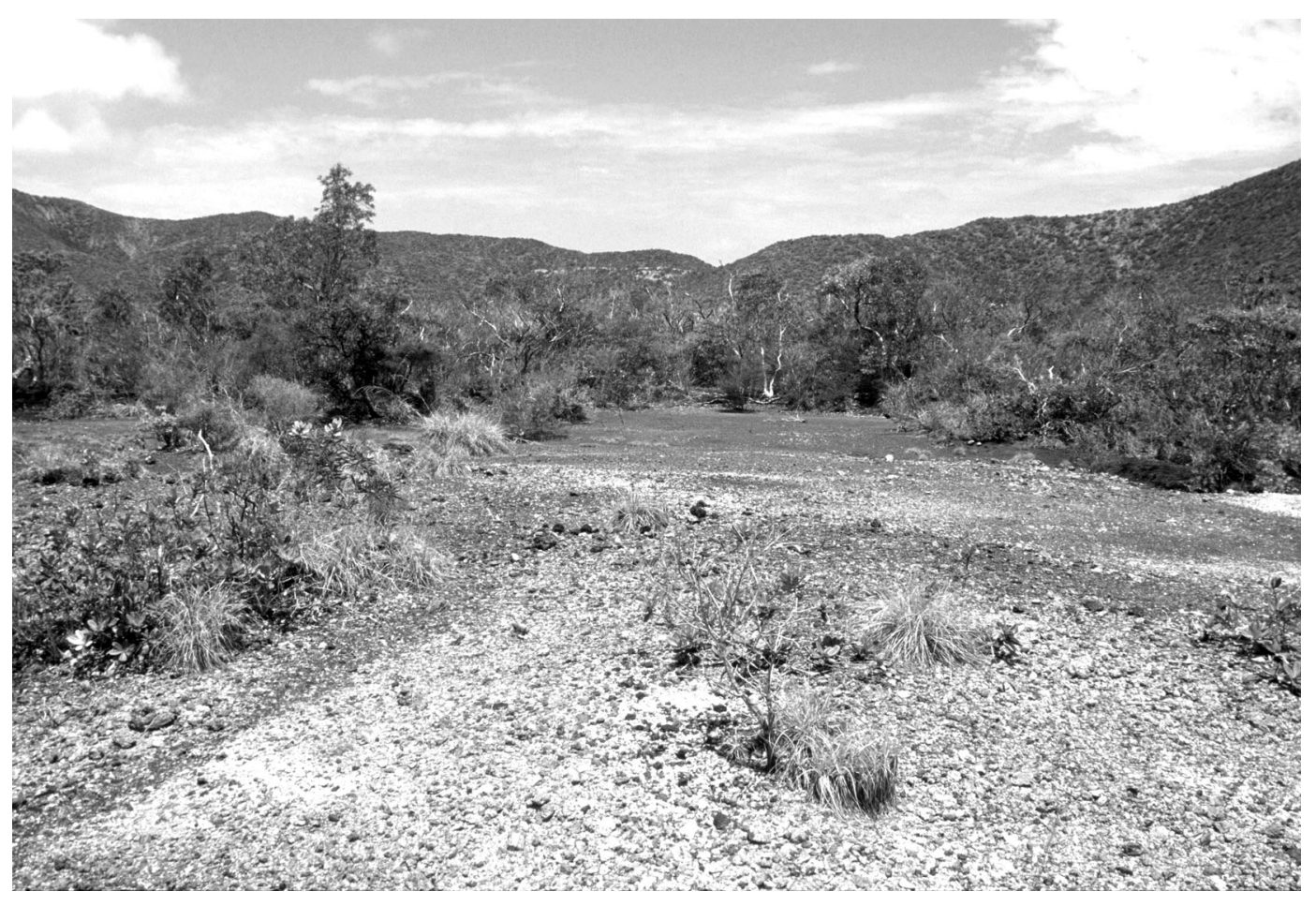

Figure 4. Habitat typical of localities at which Oedodera marmorata has been found near Paagoumène, Province Nord, New Caledonia.

this monotypic genus that would maintain monophyly is the inclusion of all New Caledonian taxa in a single genus. We deem this option inappropriate because it would lump highly divergent lineages together and disrupt accepted usage for all of the named genera in New Caledonia.

Our data suggest that Oedodera diverged from other New Caledonian diplodactylids around 22 million yr ago, using molecular clock estimates based on calibrations from the same gene region in other lizard taxa (Macey et al. 1998). This age is far younger than the geological age of New Caledonia as a subaerial landmass and considerably less than the presumed age of the New Caledonian diplodactylid radiation, which has been postulated to be of Gondwanan origin (Bauer 1990, Bauer and Sadlier 1993, 2000). However, it should be noted that the age of the basalmost cladogenetic events within the lin- eage reflects only the oldest subdivisions among extant taxa, not the origin of the clade as a whole. Indeed comparisons with $\mathrm{New}$ Zealand outgroup taxa suggest a divergence of over 80 million yr (T.J., A.M.B., S. A. Smith, and R.A.S., unpubl. data), and this interpretation is consistent with hypotheses regarding the fragmentation of the eastern Tasman landmasses following the opening of the Tasman and Coral Seas (Kroenke 1996).

\section{Conservation Status}

Given the tiny area of known occurrence (ca. $5 \mathrm{~km}^{2}$ ) and the number of possible threats, Oedodera marmorata is considered critically endangered using the criteria established for New Caledonian lizards by Sadlier and Bauer (2003). None of the area where the species occurs is protected. The maquis shrubland habitat is vulnerable to wildfires (a large part 
of the area around Paagoumène was burned in late 2002), and localized parts of the site are used for dumping rubbish. Rats and feral cats are also present at the site (Whitaker et al. 2004) and are potential predators of O. marmorata. The fire ant, Wasmannia auropunctata (Roger), was not encountered near Paagoumène, but because this invasive species is widespread in New Caledonia and is known to negatively impact native geckos (Jourdan et al. 2001) it is also considered a potential threat. However, potentially the greatest threat to the type locality is the expansion of the nickel mine on Dôme de Tiébaghi. The lower part of the Creek à Paul valley has been identified as a possible location for an extensive ore-handling and storage facility.

Unlike many other areas in New Caledonia that support locally endemic lizard species, the area around Paagoumène has not previously been recognized as biologically unique. Its herpetofauna seems otherwise to be a depauperate version of that found on the adjacent Dôme de Tiébaghi, supplemented by the two Hemidactylus species, one of which, $H$. frenatus, was introduced into New Caledonia in the 1940s and is typical of disturbed and anthropogenic habitats (Bauer and Sadlier 2000). The relative population density (encounter rate) for O. marmorata was 3.18/hr at Creek à Paul and $0.31 / \mathrm{hr}$ at Ruisseau des Gaïacs, and this abundance was in inverse proportion to the density of $\mathrm{H}$. frenatus, a species known to competitively exclude a variety of other geckos in areas where it has been introduced (Petren et al. 1993, Petren and Case 1996). Based on the success of $H$. frenatus elsewhere in New Caledonia (Bauer and Sadlier 2000), we suspect that it may pose a risk of displacement to $O$. marmorata.

We recommend that other, similar maquis areas around Dôme de Tiébaghi and elsewhere between Koumac and Poum be surveyed for Oedodera and that an effort be made to protect at least some populations within reserves of some kind. The basal position within the phylogeny of New Caledonian diplodactylids should give this taxon priority status for conservation.

\section{ACKNOWLEDGMENTS}

We are grateful to the Province Nord authorities for supporting our herpetological research in northwestern New Caledonia. Our fieldwork was carried out under Convention de Collaboration No. 80/2001 from the Direction du Développement Économique et de l'Environnement of the Assemblée de la Province Nord, and the specimens of Oedodera marmorata were collected under permits No. 31 and No. 49/02/SFE to Whitaker Consultants and permit No. 01/03/COLLSCE to A.M.B. We particularly thank Joseph Manauté, Christian Papineau, Jean-Jérome Cassan, and Van Duong Dang and the staff at the Antenne DDEE de Koumac. We are also grateful to Jean Inchauspé and Paul Atkins of Société Le Nickel (SLN) for their assistance in the Tiébaghi area. Logistical support and encouragement was provided by Jean Chazeau of IRD Nouméa, and Vivienne Whitaker, Sarah A. Smith, and Greg Watkins-Colwell participated in the fieldwork. Michael Kiebish assisted in early stages of the molecular laboratory work.

\section{Literature Cited}

Bauer, A. M. 1990. Phylogenetic systematics and biogeography of the Carphodactylini (Reptilia: Gekkonidae). Bonn. Zool. Monogr. 30:1-219.

Bauer, A. M., and R. A. Sadlier. 1993. Systematics, biogeography and conservation of the lizards of New Caledonia. Biodiv. Lett. 1:107-122.

. 2000. The herpetofauna of New Caledonia. Society for the Study of Amphibians and Reptiles, Ithaca, New York.

Böhme, W., and M. Sering. 1997. Tail squirting in Eurydactylodes: Independent evolution of caudal defensive glands in a diplodactyline gecko (Reptilia, Gekkonidae). Zool. Anz. 25:225-229.

Good, D. A., A. M. Bauer, and R. A. Sadlier. 1997. Allozyme evidence for the phylogeny of giant New Caledonian geckos (Squamata: Diplodactylidae: Rbacodactylus), with comments on the status of $R$. leachianus henkeli. Aust. J. Zool. 45:317-330. 
Han, D., K. Zhou, and A. M. Bauer. 2004. Phylogenetic relationships among gekkotan lizards inferred from C-mos nuclear DNA sequences and a new classification of the Gekkota. Biol. J. Linn. Soc. 83:353-368.

Huelsenbeck, J. P., and F. Ronquist. 2001. MRBAYES: Bayesian inference of phylogeny. Bioinformatics 17:754-755.

Jaffré, T., P. Morat, J.-M. Veillon, and H. S. MacKee. 1987. Changements dans la vegetation de la Nouvelle-Calédonie au cours du Tertiaire: La vegetation et la flore des roches ultrabasiques. Bull. Mus. Natl. Hist. Nat., 4th sér., Sect. B, Adansonia Bot. Phytochim. 9:365-391.

Jourdan, H., R. A. Sadlier, and A. M. Bauer. 2001. Little fire ant invasion (Wasmannia auropunctata) as a threat to New Caledonian lizards: Evidences from the sclerophyll forest (Hymenoptera: Formicidae). Sociobiology 38:283-301.

Kroenke, L. W. 1996. Plate tectonic development of the western and southwestern $\mathrm{Pa}$ cific: Mesozoic to the present. Pages 1934 in A. Keast and S. E. Miller, eds. The origin and evolution of Pacific island biotas, New Guinea to eastern Polynesia: Patterns and processes. SPB Academic Publishing, Amsterdam.

Macey, J. R., J. A. Schulte II, N. B. Ananjeva, A. Larson, N. Rastegar-Pouyani, S. Shammakov, and T. J. Papenfuss. 1998. Phylogenetic relationships among agamid lizards of the Laudakia caucasia complex: Testing hypotheses of fragmentation and an area cladogram for the Iranian Plateau. Mol. Phylogenet. Evol. 10:118-131.

Petren, K., and T. J. Case. 1996. An experimental demonstration of exploitation competition in an ongoing invasion. Ecology 77:118-132.

Petren, K., D. T. Bolger, and T. J. Case. 1993. Mechanisms in the competitive success of an invading sexual gecko over an asexual native. Science (Washington, D.C.) 259:354-358.
Posada, D., and K. A. Crandall. 1998. Modeltest: Testing the model of DNA substitution. Bioinformatics 14:817-818.

Sadlier, R. A., and A. M. Bauer. 2003. Conservation status of endemic New Caledonian lizards: An assessment of the distribution and threats to the species of lizards endemic to New Caledonia (http://www .amonline.net.au/herpetology/research/ lizards_conservation_intro.htm).

Sadlier, R. A., S. A. Smith, A. M. Bauer, and A. H. Whitaker. 2004. A new genus and species of live-bearing scincid lizard (Reptilia: Scincidae) from New Caledonia. J. Herpetol. 38:117-127.

Sautter, G., coord. 1981. Atlas de la Nouvelle Calédonie et Dépendances. O.R.S.T.O.M., Paris.

Swofford, D. L. 2002. PAUP*: Phylogenetic analysis using parsimony (*and other methods), version 4.0. Sinauer Associates, Sunderland, Massachusetts.

Vences, M., F.-W.Henkel, and R. Seipp. 2001. Molekulare Untersuchungen zur Phylogenie und Taxonomie der Neukaledonischen Geckos der Gattung Rhacodactylus (Reptilia: Gekkonidae). Salamandra 37:73-82.

Whitaker, A. H., R. A. Sadlier, A. M. Bauer, and V. A. Whitaker. 2004. Biodiversity and conservation status of lizards in threatened and restricted habitats of north-western New Caledonia. Report by Whitaker Consultants Limited to Direction du Développement Économique et de l'Environnement, Province Nord, Koné.

Wright, J. L. 1999. The phylogeny of Bavayia (Reptilia: Diplodactylidae) based on mitochondrial DNA, allozymes and morphological evidence, including the description of two new species. M.S. thesis, Villanova University, Villanova, Pennsylvania.

Wright, J. L., A. M. Bauer, and R. A. Sadlier. 2000. Two new gecko species allied to $B a$ vayia sauvagii and Bavayia cyclura (Reptilia: Squamata: Diplodactylidae) from New Caledonia. Pac. Sci. 54:39-55. 
